\title{
Normative Labels in Two Lexicographic Traditions: A Slovene-English Case Study
}

\author{
Marjeta Vrbinc, Faculty of Arts, University of Ljubljana, Slovenia \\ (marjeta.vrbinc@ff.uni-lj.si) \\ Danko Šipka, School for International Letters and Cultures, Arizona State \\ University, Tempe Campus, USA (danko.sipka@asu.edu) \\ and \\ Alenka Vrbinc, School of Economics and Business, University of Ljubljana, \\ Slovenia (alenka.vrbinc@ef.uni-lj.si)
}

\begin{abstract}
This article presents and discusses the findings of a study conducted with the users of Slovene and American monolingual dictionaries. The aim was to investigate how native speakers of Slovene and American English interpret select normative labels in monolingual dictionaries. The data were obtained by questionnaires developed to elicit monolingual dictionary users' attitudes toward normative labels and the effects the labels have on dictionary users. The results show that a higher level of prescriptivism in the Slovene linguistic culture is reflected in the Slovene respondents' perception of the labels (for example, a stronger effect of the normative labels, a higher approval for the claim about usefulness of the labels, a considerably lower general level of acceptance for the standard language) when compared with the American respondents' perception, since the American linguistic culture tends to be more descriptive. However, users often seek answers to their linguistic questions in dictionaries, which means that they expect at least a certain degree of normativity. Therefore, a balance between descriptive and prescriptive approaches should be found, since both of them affect the users.
\end{abstract}

Keywords: GENERAL MONOLINGUAL DICTIONARY, PRESCRIPTIVISM, NORMATIVITY, DESCRIPTIVISM, NORMATIVE LABELS, PRIMARY EXCLUSION LABELS, SECONDARY EXCLUSION LABELS, USE OF LABELS, USEFULNESS OF LABELS, (UN)LABELED ENTRIES

Opsomming: Normatiewe etikette in twee leksikografiese tradisies: 'n Sloweens-Engelse gevallestudie. In hierdie artikel word die bevindings van 'n studie wat uitgevoer is op gebruikers van eentalige Sloweense en Amerikaanse woordeboeke voorgelê en bespreek. Die doel van die artikel was om te bepaal hoe moedertaalsprekers van Sloweens en Amerikaanse Engels sekere normatiewe etikette in eentalige woordeboeke interpreteer. Die data is verkry deur vraelyste te ontwikkel wat die ingesteldheid van gebruikers van eentalige woordeboeke teenoor normatiewe etikette en die effek daarvan op woordeboekgebruikers belig. Die resultate dui daarop dat ' $n$ hoër vlak van preskriptiwiteit in die Sloweense taalkundige kultuur waargeneem word in die Sloweense respondente se begrip van die etikette (byvoorbeeld, 'n sterker invloed van die normatiewe etikette, 'n groter goedkeuring van die stelling oor die bruikbaarheid van die etikette, ' $n$ aansienlik laer algemene aannamevlak by die standaardtaal) wanneer dit ver- 
gelyk word met die persepsie van die Amerikaanse respondente, aangesien die Amerikaanse taalkundige kultuur geneig is om meer deskriptief te wees. Gebruikers soek egter dikwels in woordeboeke antwoorde op hul taalkundige vrae, wat daarop dui dat hulle ten minste 'n sekere graad van normatiwiteit verwag. Aangesien albei benaderings die gebruikers beïnvloed, moet daar ' $n$ balans tussen deskriptiewe en preskriptiewe benaderings gevind word.

Sleutelwoorde: ALGEMENE EENTALIGE WOORDEBOEK, PRESKRIPTIWITEIT, NORMATIWITEIT, DESKRIPTIWITEIT, NORMATIEWE ETIKETTE, PRIMÊRE UITSLUITINGSETIKETTE, SEKONDÊRE UITSLUITINGSETIKETTE, GEBRUIK VAN ETIKETTE, BRUIKBAARHEID VAN ETIKETTE, (ON)GEËTIKETTEERDE INSKRYWINGS

\section{Introduction}

While the cultural tradition of the Slovene language features linguistically strong prescriptive attitudes and practices, in American English, the linguistic prescriptivism has been much more subdued. This disparity leads to questions about the differences in the effect that the means of linguistic prescriptivism have on the speakers of these two languages. In order to find answers to these questions, a study was carried out, which was aimed at discerning the effect the normative labels have on the speakers of the respective languages.

Normative labels are the qualifiers, and they include slang, incorrect usage, etc., which exclude single words, one or more of its senses, or one or more of its phonetic or inflectional forms from their usage in the formal standard language ${ }^{1}$. Usage, in turn, in a broader sense, pertains to relationships of words or their features (their senses, their phonetic or inflectional forms) to their linguistic context. They range from the required morphosyntactic to semantic combinations to the effects the words create in that context. In a narrower sense, usage does not encompass any phonetic, phonological, prosodic, morphosyntactic, and core semantic features. In this sense, usage pertains to a higher, lower, or absolute affinity of the word or its feature toward certain contexts (e.g., toward a certain period in time or in regard to one geographical region) or a certain contextual effect (e.g., offensiveness, obscenity, etc.). Usage will be employed here in this narrower sense. Usage labels, having in mind that the narrower sense of the term usage is employed here, pertain to compact customary references to the affinity of the words or their features, and toward certain contexts or contextual effects. Hausmann (1989: 651) has identified the following criteria for deploying usage labels: time (e.g., archaism), place (e.g., regionalism), nationality (e.g., foreign word), medium (e.g., colloquial), sociocultural (e.g., slang), formality (e.g., informal), text type (e.g., poetic), technicality (e.g., biology), frequency (e.g., rare), attitude (e.g., facetious), and normativity (e.g., nonstandard). The majority of these types of labels have the capacity of serving as normative exclusion labels given that they have the potential of excluding a lexeme or its meaning from the standard language variety in its narrower sense (those contexts such as media outlets, courts, and similar others, but not related 
to literature or the spontaneous common parlance, such as creative composition). The labels that exclude most directly are the ones based on normativity. Straightforward exclusion can additionally be achieved by the criteria time and place as well as by sociocultural criteria. All the aforementioned labels exclude any given word from the modern standard language variety in its narrower sense. Some formality labels (e.g., informal) and attitude labels (e.g., derogatory) have the potential of being indirectly excluded. Their primary role is to mark the attitude, but they also have a certain potential of being interpreted by the users as exclusion labels. Other labels used in dictionaries do not have this potential. They just mark an area or a feature within a standard language variety.

The following two types of normative exclusion labels are present in all monolingual descriptive dictionaries:

a. Primary exclusion labels, e.g.: dialectal, where the dictionary compiler's goal is to clearly exclude the word, one or more of its senses, or one or more of its forms from the standard language variety;

b. Secondary exclusion labels, e.g.: obscene, where the compiler uses the label to mark something else (the attitude in this case), but the users can interpret the label as being excluded from the standard language variety.

In hands-on application, these two types blend into one another. There is a continuum of exclusiveness from a clear exclusion from the standard language variety on one end, to a weak exclusion effect on the other end of the same continuum.

The present study attempts to answer the following research questions:

a. How does the type of a normative label influence the level of acceptability of labeled words in the standard language variety?

b. What are the users' attitudes toward normative dictionary labels?

c. How does a lemma or one of its senses get labeled or how does it not affect the level of acceptability of labeled words in the standard language variety?

d. What are the differences between Slovene and American English users in items of the content of the above questions a-c?

\section{Theoretical background}

\subsection{The prescriptivist vs descriptivist divide}

The battle between prescriptivist and descriptivist approaches has existed in lexicography since the very beginning of dictionary-making activities (Finegan 2020). The prescriptivist tradition has been much more prevalent than the descriptivist one not only in lexicography but also in other branches of linguistics, which is reflected in various types of reference books produced by linguists and con- 
sulted by members of a language community to resolve their linguistic issues and dilemmas. The two most common reference books considered essential by any language community are a dictionary and a grammar book. Besides that, the linguistic tradition of Slavonic languages has relied heavily on another type of reference book called the manual of orthography, which is the closest counterpart of a manual of style in the American tradition. This means that not only lexicographers but also grammarians and those who work on orthography are also faced with the same prescriptivist vs descriptivist controversy.

Traditionally, the making of dictionaries was associated with conservatism and historically, dictionaries were compiled with prescriptivism in mind (Balteiro 2011: 278). Because the term prescriptive has a rather negative connotation, metalexicographers prefer the term normative to prescriptive (Béjoint 2010: 80). A prescriptive dictionary is typically a dictionary with only 'acceptable' words included in the wordlist, meaning that there are no words that can be considered 'unacceptable'. If 'unacceptable' words or senses are not omitted altogether, the dictionary clearly labels the disapproval (Béjoint 2010: 80). Lexicographers compiling a general mono- or bilingual dictionary should know that all the normative elements in the dictionaries may affect (some) users who are likely to take them into consideration. This is why a lexicographer should include normative information on purpose, which is possible mainly when it comes to orthography and pronunciation. To a limited extent, this may also apply to some other areas (Zgusta 1971: 290). The lexical meaning of a lemma or its senses is much more problematic, but even here the normative information will be followed by more "hesitating users" (Zgusta 1971: 291). According to Miłkowski (2013: 176), not only purists but also users in general are often emotionally involved in the issues concerning the correct use; on the other hand, not all stable linguistic patterns found in a corpus with a high frequency can become standard. At the same time, users often ignore the authority of the experts and it is also true that some norms set by experts are disregarded by most users of a language, which is why traditional prescriptivism has no place in contemporary linguistics. Prescriptivism as practiced in contemporary linguistics is well explained by Armstrong and Mackenzie (2015: 29), who claim that it is "the expression of an ideology, one which is anchored both in human psychology and in a broader, hierarchical conception of how society should be organized."

Nowadays, linguistics in general and especially its corpora-based part, favors descriptivism (Finegan 2003), which is indicative of a broader trend of abandoning prescriptivism in linguistics. This trend is also observed in lexicography, since lexicographers mostly claim that the dictionary they compiled only describes the language, as it is without giving its users advice on what is correct or desired and without making a distinction between good or bad. However, users consulting a dictionary often try to find out what is correct and what is incorrect, which clearly shows that they do expect a certain degree of prescriptivism. Therefore, a dictionary cannot be based on a descriptive 
approach only, which is what Béjoint (2010: 80) clearly emphasizes by saying: "Pure descriptivism is impossible." The lexicographers working on a particular dictionary have to decide what to include and what to exclude from it and this is why all dictionaries represent a certain model of linguistic usage. This is also in line with Yong and Peng (2007: 116), who claim that "a dictionary that rids itself of all traces of value-judgement and does not give stylistic and register labels of any kind to particular lexical items is bound to stir up severe criticisms and raise a public outcry."

When it comes to setting the norm, frequency in large databases is of the utmost importance, but lexicographers using corpora for the dictionary compilation process have to be aware of the fact that due to qualitative limits of the corpora used, absolute objectivity of the description is not to be expected (Jarošová and Benko 2012: 259). The most common criteria for the inclusion of material into dictionaries are authenticity and representativeness. However, any dictionary on the market, even if it claims to be descriptive, has a great normative power, which means that even if one particular incorrect spelling of a word appears with a high frequency in a representative corpus, that does not mean that such a spelling would merit inclusion in a general dictionary (Svensén 2009: 67). It is essential to avoid using simple approaches to the description of a language. Both descriptivism based on corpus analyses and prescriptivism based on expert authority seem to disregard the dynamics of language change (Miłkowski 2013: 175). The two approaches use different norms. For descriptivists, the most important criterion is quantity, which means that a form is acceptable if it is used by a considerable number of users. However, it is difficult to determine the minimum number of users or uses of a certain linguistic form to be considered acceptable (Béjoint 2010: 80). Frequency of use and statistically relevant use are not really the only criteria that should be met for a linguistic phenomenon to become an accepted norm. Prescriptive dictionaries use a qualitative norm on the basis of the use of language by the most proficient users. The issue that needs to be addressed is the uncertainty of which model to choose. As Béjoint (2010: 80) states: "It is always written rather than spoken, and literary, and typically from some time before the compilation of a dictionary. The qualitative norm corresponds to the eighteenth-century type of corpus, giving priority to aesthetic judgement over frequency." Very often, users of a language simply disregard the rules set by experts as these may often be outdated in terms of the development of a language (Miłkowski 2013: 177).

The issue with prescriptivism and descriptivism is often conditioned by tradition and cultural factors. Most certainly, culture plays an important role and determines different approaches used in different countries, societies or language communities. In nations with an academy of science, such as the Italian Accademia della Crusca, the French Academy (Académie française), the Royal Spanish Academy (Real Academia Española) and Slovenian Academy of Sciences and Arts (Slovenska akademija znanosti in umetnosti), the authority rests with these academies in setting the norm for a language, or more precisely, in 
determining what is correct or not in terms of grammar, syntax, spelling or the lexis². The authority of an institution is also reflected in the fact that language users are given the opportunity to pose questions to linguists about how to use the language correctly. This is obvious not only in Slovenia, but also in other countries with an authoritative institution (e.g., Poland, where numerous linguistic consulting websites exist and are popular (Miłkowski 2013: 176)). In Slovenia, the perception of authority was confirmed in a study carried out in 2018 by one of the interviewees who explained that one of her duties as an employee of the Academy was to provide answers to questions language users asked within the framework of the consulting service of the Academy. She stated that the general public had great confidence and trust in the authority of the Academy and its staff because people believed her, even when she herself was not entirely satisfied with the answers she provided (Vrbinc et al. 2018: 374). Here, a question can be raised why language users use consulting services if it is usage that determines linguistic standards (for more on this issue, see Miłkowski 2013).

\subsection{Prescriptivism and descriptivism in the lexicographic tradition of the English language}

The lexicography of English can be traced back to the Old English period (more Anglo-Saxon and Germanic than its modern counterpart), around 1150 when words in Latin manuscripts were glossed into English. Glosses were later collected and appeared in glossaries which can be considered the forerunners of modern bilingual dictionaries (for more on this issue, see Landau 2001: 45; Béjoint 2010: 52-55). The first true English monolingual dictionary entitled A Table Alphabeticall, conteyning and teaching the true writing, and onderstanding of hard vsuall English wordes, borrowed from the Hebrew, Greeke, Latine, or French, etc. was published in 1604 by Robert Cawdr(e)y, who chose the words from Thomas Thomas's Latin-English dictionary (Dictionarium Linguae et Anglicanae) published in 1587, as well as from earlier grammar books (Landau 2001: 43). It was not just English whose first monolingual dictionary appeared at the beginning of the 17th century, but also some other European languages got their first monolingual dictionaries at approximately the same time as part of the grammaticalization of vernacular languages, since it became clear that vernacular languages could also have a grammar like Latin and could be codified. The first encyclopedia in English was published in 1728 by Ephraim Chambers (Cyclopaedia: Or an Universal Dictionary of Arts and Sciences), who advocated the creation of an authority on language following the examples of France and Italy, where the academies as language regulators had already been established; however, Chambers believed that this was not a lexicographer's job and spoke in favor of a more descriptive approach, since a dictionary should only record usage (Béjoint 2010: 56; 61). 
The 18th century was considered a turning point in lexicography due to the development of science and technology as well as due to the fact that more people wrote and more periodicals appeared. In England, the first decade of the 18th century saw the publication of as many as five dictionaries. It is important to stress that it was only in the 18th century when the idea that dictionaries could exert a regulatory influence on a language emerged (Béjoint 2010: 63-64; 79). The main event in English lexicography of the 18th century was the publication of Samuel Johnson's Dictionary of the English Language: In Which the Words are Deduced from Their Originals, and Illustrated in Their Different Significations, by Examples from the Best Writers, to Which are Prefixed a History of the Language, and an English Grammar (1755), which was written on the initiative of a group of publishers who asked Johnson to create an authoritative dictionary of English (Lynch 2003). Johnson's Dictionary was both descriptive and prescriptive (Landau 2001: 63). It was the pre-eminent British dictionary until the completion of the Oxford English Dictionary (1928). It is among the most renowned and influential dictionaries of the English language, its influence extending beyond Britain and beyond English.

Some of the principles used by Johnson (e.g., the use of literary quotations, definitions in historical sequence) are employed by the Oxford English Dictionary (OED), which is believed to follow a descriptive approach, but as Brewer (2010: 24) claims the editors of its first edition "included a number of judgements, expressions of opinion, and recommendations on language which now appear to us clearly prescriptive, not descriptive." Béjoint (2010: 102-103) agrees that the OED can be labeled as being a descriptive dictionary, but like all other dictionaries, its lexicographers had to choose words, usages and spellings when different variants existed. In OED1, a paragraph mark (II) is used by the editors to indicate what they are objecting to in a current (or past) usage of the entry word or one of its senses. The paragraph mark, however, is not always used to indicate value judgements, as sometimes they stand alone in a headnote or other explanatory matter accompanying the definition (Brewer 2010: 25). Another very clear indication of a prescriptive approach used in the OED is that rude words are excluded from the wordlist "motivated by notions of propriety and social nicety akin to those informing the disapproving comments on inelegance and misuse" (Brewer 2010: 27). Besides the linguistic norms, the social aspect exerts considerable influence on usage. Expressions that carry offensive connotations, mostly words relating to sex and excretory functions as well as expressions with unacceptable value judgement regarding sex, race, nationality, social class, religion, etc., belong to the part of the vocabulary of every language that is considered socially sensitive (Svensén 2009: 67-68). Apart from its declared descriptiveness, the OED also included derogatory labels, such as low, vulgar, illiterate (Béjoint 2010: 103), which clearly express advice to the user which words or senses to avoid. The latest edition of OED published online (3rd edition) no longer has paragraph marks and it no longer makes negative judgements when describing usage, which can be regarded as a 
trend toward descriptivism. In Brewer's words (2010: 30): "for the first time, OED is truly living up to its claim to be an historian of the language rather than a critic of it."

Johnson's Dictionary also had a significant influence on American lexicography, since Johnson was considered the seminal authority on language for Americans in the second half of the 18th century and American lexicography was colored by his fame (Hitchings 2005: 224). Joseph E. Worcester wrote in the Introduction to his dictionary, A Universal and Critical Dictionary of the English Language, published in 1846 that Johnson's Dictionary "from the time of its first publication, has been, far more than any other, regarded as a standard for language." The Dictionary was revised by Henry John Todd and came to be known as Todd-Johnson. Since the first dictionaries used in America were produced in Britain and only very few small dictionaries were published in America at the end of the 18th century, the true beginning of American lexicography was the publication of Noah Webster's American Dictionary of the English Language in 1828, which was compiled with the intention of replacing Todd-Johnson in America as the standard work (Landau 2001: 66; Béjoint 2010: 84-85). Unlike Johnson, Webster did not want to "fix" the language but welcomed change (Landau 2001: 69). However, Webster also had strong opinions on what was proper and what was not and he also had significant influence on American spelling (Schulman and Lepore 2008: 57; Landau 2001: 70-71). In 1890, Webster's International Dictionary, called The International, was published with the aim of being an authority on all varieties of English.

Apart from Webster, Worcester was another lexicographer whose dictionaries dominated the American market in the mid-19th century, his most important dictionary being A Dictionary of the English Language (1860). If we compare Webster's and Worcester's attitude toward descriptivism and prescriptivism in lexicography, we can claim that Webster tried to standardize the language and was essentially prescriptive, although he later moved away from prescriptivism realizing how hopeless the task was (Laird 1970: 263 ff.). Worcester, on the other hand, believed that it was not the function of the dictionary to standardize any part of the language; in his opinion, the function of the dictionary is to record constant changes in the language (Martin 2019).

In the second half of the 19th century, dictionaries increased in importance among Americans for various reasons: the search for linguistic knowledge grew; industrialization happened and technology advanced, which resulted in new vocabulary; the growth of the population and public education as a means of self-improvement that resulted in a huge demand for books, while also teaching immigrants and others how to speak and write correctly (Adams 2015: 25). Dictionaries began to be perceived as authorities, since their users expected them to provide answers to their questions about usage, pronunciation, etymology, and the like, or in other words, their users expected them to be prescriptive (Landau 2001: 85; Béjoint 2010: 90-91).

The revised edition of Webster's International Dictionary, entitled Webster's 
New International Dictionary was published in 1909. The second edition of Webster's New International Dictionary (1934) was the ultimate authority on meaning and usage and it dominated the market for unabridged dictionaries until the 1960s (Morton 1994: 2; 39). In 1961, the third edition of Webster's New International Dictionary came out, which was descriptive, reflecting the view of its editor Philip B. Gove (1967: 7), who pointed out that "Lexicography should have no traffic with guesswork, prejudice, or bias, or with artificial notions of correctness and superiority. It must be descriptive and not prescriptive." The descriptive approach of the dictionary was not well accepted by those who believe that a dictionary should serve as a standard of correctness, thus being prescriptive (Morton 1994: 7; Béjoint 2010: 134). In 1966, The Random House Dictionary was published which was intended to be fully descriptive and saw a revised edition in 1987 (Morton 1994: 284). The publication of the American Heritage Dictionary of the English Language in 1969 should be understood as a reaction against the descriptive approach of Webster's Third (Adams 2015: 17), being selfdescribed as more prescriptive than its competitors (Morton 1994: 285). In the Introduction to the American Heritage Dictionary, the editor-in-chief, William Morris states that the dictionary "would faithfully record our language, the duty of any lexicographer", but he adds that the dictionary "would add the essential dimension of guidance, that sensible guidance toward grace and precision of the American public" (Morris 1969: vi). However, the first edition also included elements that pointed towards a more descriptive direction. Successive editions (1982, 1992, 2000 and 2011) qualified the dictionary's prescriptive tendencies, yet, in the course of time, the dictionary changed in ways that reflect the descriptive approach (Adams 2015: 17-18; 25; 32). Despite a growing trend toward description, all five editions of the American Heritage Dictionary are still regarded as normative (Adams 2015: 41).

It can be said that the prominence of linguistic prescriptivism in English was set at the level considerably lower than in numerous other European languages very early on. One can trace this attitude to the following statement in Samuel Johnson's Dictionary:

[...] academies have been instituted, to guard the avenues of their languages, to retain fugitives, and repulse intruders; but their vigilance and activity have hitherto been vain; sounds are too volatile and subtile for legal restraints; to enchain syllables, and to lash the wind, are equally the undertakings of pride, unwilling to measure its desires by its strength. The French language has visibly changed under the inspection of the academy; the stile of Amelot's translation of Father Paul is observed, by Le Courayer to be un peu passé; and no Italian will maintain that the diction of any modern writer is not perceptibly different from that of Boccace, Machiavel, or Caro. (Johnson 1755: Preface: 10)

As we could see from the above overview, prescriptivism is present in the cultures and linguistic traditions of the English-speaking world in the Northern Hemisphere. The authority for prescriptive usage in English is not very clear, the reason being the absence of normatively inclined institutions like language 
academies, and there are various and changing referents like the Oxford English Dictionary, the American Heritage Dictionary, and the like (Balteiro 2011: 285). British dictionaries have been more descriptive than prescriptive, which is due to the influence of Johnson's Dictionary and OED (Béjoint 2010: 154). America might be expected to be particularly open to lexicographic description, but surprisingly, Americans have long embraced prescriptive attitude toward language. Prescriptivism is no longer a hot issue in America and the late twentieth century American lexicography is characterized by the descriptive approach (Béjoint 2010: 155; Adams 2015: 18-20).

\subsection{Prescriptivism and descriptivism in the lexicographic tradition of the Slovene language}

As stated in Section 2.1, Slavonic languages are characterized by a reference book trio: a dictionary, along with a grammar book and a manual of orthography. A look into the history of linguistic development in Slovenia shows that the first reference books go back to the 16th century, to the works of the Protestant writers who were strongly influenced by the German Protestant Reformation movement. The most notable Slovene Protestant Primož Trubar is regarded as the key figure of Slovene cultural history who is also notable for consolidating the Slovene language. The first proper dictionaries were published at the end of the 16th century by the German lexicographer named Hieronymus Megiser. These dictionaries were multilingual, Slovene being one among many target languages. The multilingual dictionaries formed a basis for the development of bilingual dictionaries that followed, whereas monolingual lexicography in Slovenia developed relatively late.

The first Slovene monolingual dictionary was compiled by Joža Glonar and came out as late as 1936. Glonar adopted a more prescriptive approach as he tried to follow linguistic rules when describing the language (Dobrovoljc 2004: 65-66). The compilation of the first institutional monolingual Slovene dictionary began in the 1950s. The Dictionary of Standard Slovene (DSS) appeared in five volumes and the final, fifth, volume came out in 1991. The second edition with minor changes and corrections was published in 2014. These two editions are characterized by strict adherence to normativity and prescriptivism. In 2016, work on an entirely new dictionary of standard Slovene began (eSSKJ: Slovar slovenskega knjižnega jezika - e-Dictionary of Standard Slovene). The first and the second editions of the DSS claim to include a variety of variant forms and language peculiarities. The lexicographers admit openly that their approach is normative, but at the same time they strive towards objectivity to the greatest possible degree. The compilers of the eDSS, however, moved away from prescriptivism to language description, but partly they retain the normative role typical of manuals of orthography. For more information on the inclusion of normative information in the DSS and eDSS, see Šipka et al. 2020. 
Compared to monolingual dictionaries, grammar books of Slovene can be traced back to the end of the 16th century. The first grammar book was published in 1584 by Adam Bohorič and was didactically oriented (meant to serve moral teaching as well). Numerous other grammar books were published in the centuries that followed, some didactic, some didactic with normative tendencies and others with pure normative orientation. The most influential grammar book was published in 1976 by Jože Toporišič. It is considered the highest authority in the field of grammar and is currently the single most quoted grammar book in Slovenia (Marušič and Žaucer 2015).

The reference book that has been of the utmost importance in setting the norm for the Slovene standard language has been the manual of orthography. Many different manuals of Slovene orthography typically consist of two parts: the first part contains theoretical rules relating to orthography, pronunciation, inflectional paradigms, syntactic rules and style; the second part is the dictionary part that exhibits the rules explained in the first part. The first manual of orthography was published in the second half of the 19th century by Fran Levec and was didactic in nature; this is why it was used as a school textbook (Dobrovoljc 2015a). The 20th century saw the publication of numerous other manuals of orthography that were first published by individual scholars and were characterized by a strong normative note. The first manual of orthography to be published under the auspices of an institution (the Orthographic Committee of the Scholarly Society in Ljubljana) was authored by Anton Breznik and Fran Ramovš. It came out in 1935, and it is descriptive in nature, meaning that it allows the users to make a choice about the variants included in the manual (Dobrovoljc 2015b). In 2001, a completely new Manual of Slovene Orthography was published. It was edited by the grammarian Jože Toporišič and others. This Manual is based on Toporišič's (1976) grammar book and follows the tradition of normative manuals of orthography (Dobrovoljc 2015c).

Bearing all these historical developments in mind, the study into the effect of normative labels in contemporary dictionaries on their users was conducted. The findings of this study are presented and discussed in the following sections.

\section{Research design}

The study was carried out with Slovene and American students who are likely to use monolingual dictionaries in general (e.g., in writing their assignments). We wanted to get an insight into how native speakers of Slovene and American English interpret select normative labels in monolingual general dictionaries. For this purpose, we prepared a questionnaire, which was distributed in early November 2019 to the undergraduate students of economics and English at the University of Ljubljana, Slovenia. The US survey was conducted in late January 2020 with the students of English and International Letters and Cultures at Arizona State University. A total of 105 students provided their responses to all 
questions in the Slovene survey, while 112 participants provided their responses to all questions in the US survey ${ }^{3}$.

The questionnaire was developed with the aim of eliciting monolingual dictionary users' attitudes toward normative labels and the effects the labels have on dictionary users. The Slovene questionnaire is provided in Appendix 1. The US questionnaire can be found in Appendix 2. The questionnaire consists of three parts based on the type of information we wanted to obtain. The first part (Question 1) includes the labels colloquial, dialectal, incorrect, and obsolete belonging to primary exclusion labels. The purpose of primary exclusion labels is to exclude a word or its meaning from the contemporary standard language. The four primary exclusion labels are mixed with four secondary exclusion labels (expressive, facetious, ironic, vulgar) whose primary purpose differs from that of primary exclusion labels. Secondary exclusion labels can still be interpreted as excluding a lemma or one of its senses from contemporary standard language. Our respondents were asked how often a lemma or one of its senses marked with one of the aforementioned labels is used in the contemporary standard language (always, often, sometimes, rarely, never). Question 1 aims at discerning how our respondents interpret these labels as such, i.e., in isolation from the words that are labeled. The second part, which comprises of three questions, inquiries about whether these labels are useful (Question 2), whether respondents pay attention to them (Question 3), and whether a more precise division within the field of colloquialism would be useful (Question 4). The purpose of these questions was to gather information about users' general attitudes toward this type of labels. The final part of the questionnaire (Question 5) asks if the selected words are used in the standard language (using a Likert scale: strongly agree, agree, no opinion, disagree, strongly disagree). There are four pairs of words. In each pair, the words share a common characteristic, e.g., both words in a pair are colloquial but just one of them is labeled colloquial, whereas the other one does not have any label. The purpose of Question 5 was to see whether the labels have any effect on dictionary users.

\section{Results}

As indicated in Section 1, the present research was meant to provide answers to the following questions, comparing Slovene and US data:

a. How does a type of normative labels influence the level of acceptability of labeled words in the standard language variety?

b. What are the users' attitudes toward normative dictionary labels?

c. How does the fact that a lemma or one of its senses marked with a normative label affect the level of acceptability of labeled words in the standard language variety?

The results relating from these three questions will be discussed in turn below. 


\subsection{Primary vs secondary exclusion labels}

For both, the Slovene and the US surveys, an independent-sample t-test was conducted to compare the levels of the standard language usage of primary and secondary exclusion labels (Question 1). In the Slovene survey, there was no significant difference in the level of standard language use for primary labels $(\mathrm{M}=2.60, \mathrm{SD}=1.21)$ and secondary levels $(\mathrm{M}=2.75, \mathrm{SD}=1.12) ; \mathrm{t}(838)=-1.84$, $\mathrm{p}=.067$. As can be seen, primary exclusion labels have a somewhat lower degree of standard language use, but the difference is not statistically significant, although it is very close to that status. In the US survey, however, there was a significant difference in the level of standard language use for primary exclusion labels $(\mathrm{M}=2.97, \mathrm{SD}=1.19)$ and secondary exclusion labels $(\mathrm{M}=3.26$, $\mathrm{SD}=1.21) ; \mathrm{t}(894)=-3.65, \mathrm{p}=.000$. As can be seen, primary exclusion labels have a lower degree of standard language use. The standard language use of individual labels is presented in Table 1.

Table 1: Standard language use of individual labels

\begin{tabular}{|c|c|c|c|c|c|c|}
\hline & \multicolumn{3}{|l|}{ Slovene } & \multicolumn{3}{|l|}{ US } \\
\hline & Type & $\mathrm{N}$ & Mean & $\mathrm{N}$ & Mean & $\begin{array}{l}\text { Std. } \\
\text { Deviation }\end{array}$ \\
\hline colloquial & primary & 105 & 3.03 & 112 & 3.34 & 1.03 \\
\hline dialectal & primary & 105 & 2.39 & 112 & 3.19 & .87 \\
\hline incorrect & primary & 105 & 2.37 & 112 & 2.65 & 1.45 \\
\hline obsolete & primary & 105 & 2.61 & 112 & 2.70 & 1.20 \\
\hline expressive & secondary & 105 & 3.12 & 112 & 3.85 & .95 \\
\hline facetious & secondary & 105 & 2.79 & 112 & 2.92 & 1.03 \\
\hline ironic & secondary & 105 & 3.10 & 112 & 3.45 & 1.11 \\
\hline vulgar & secondary & 105 & 1.97 & 112 & 2.83 & 1.42 \\
\hline
\end{tabular}

In the Slovene study, the results show that the main contributor to the exclusion among secondary labels is the label vulgar. Also, given that Slovene dic- 
tionaries contain both colloquial and lower colloquial, the primary label colloquial is considerably less exclusive than other primary labels. This points to the fact that the difference between primary and secondary colloquial labels could be even higher with other labels in lieu of the aforementioned two. The US data show that the main contributors to the exclusion among secondary labels are the labels vulgar and facetious. Among primary labels, colloquial and dialectal are considerably less exclusive than other primary labels.

What is most remarkable in comparison of the two datasets is a higher level of acceptance for the use of labeled dictionary entries in the standard language variety in US respondents across the board. The average value for acceptance is 2.67 for Slovene respondents and 3.12 for US respondents.

\subsection{Usefulness and use of labels}

The data obtained from the responses to Questions 2, 3 and 4 (Table 2) show that there is a difference between the cognitive component of the attitude about usage labels (there is a relatively high acceptance for the idea that they are generally useful) and the behavioral component of that attitude (the respondents use them at a lower degree). One can also see that the belief that the division inside the label colloquial (standard colloquial vs non-standard colloquial) is useful only slightly above the neutral point (with three being the mid-point of the 1-5 scale).

Table 2: Usefulness and use of labels

\begin{tabular}{|l|l|l|l|l|l|l|}
\hline \multicolumn{2}{|l|}{ Slovene } & \multicolumn{2}{l|}{ US } \\
\hline & Useful & $\begin{array}{l}\text { I use } \\
\text { them }\end{array}$ & $\begin{array}{l}\text { Higher vs lower } \\
\text { colloquial useful }\end{array}$ & Useful & $\begin{array}{l}\text { I use } \\
\text { them }\end{array}$ & $\begin{array}{l}\text { Higher vs lower } \\
\text { colloquial useful }\end{array}$ \\
\hline $\mathrm{N}$ & 105 & 105 & 105 & 112 & 112 & 112 \\
\hline Mean & 4.10 & 3.22 & 3.24 & 3.92 & 3.12 & 3.24 \\
\hline SD & .843 & 1.18 & .90 & .818 & 3.38 & .942 \\
\hline
\end{tabular}

The Slovene and US data are remarkably similar, the only difference being a higher positive attitude of the Slovene respondents about the usefulness of the labels. 


\subsection{Labeled vs unlabeled entries}

For both groups of respondents, an independent-samples t-test was conducted to compare the level of acceptance for the use in the standard language variety in labeled and unlabeled entries (Question 5). In the Slovene dataset, there was a significant difference in the level of acceptability for labeled entries $(\mathrm{M}=2.58$, $\mathrm{SD}=1.28)$ and non-labeled entries $(\mathrm{M}=2.94, \mathrm{~S}=1.30) ; \mathrm{t}(838)=-4.05, \mathrm{p}=.000$. As can be seen, labeled entries have a lower degree of acceptability. The acceptability of individual entries is presented in Table 3.

Table 3: Acceptability of individual entries in the Slovene study

\begin{tabular}{|l|l|l|l|l|l|l|l|l|}
\hline & 1ybaksis & 1nsekirati & 2ydeci & 2ndeka & 3ydeka & 3nhohštapler & 4ncoprnik & 4yfajfa \\
\hline $\mathrm{N}$ & 105 & 105 & 105 & 105 & 105 & 105 & 105 & 1.05 \\
\hline Mean & 1.77 & 3.30 & 3.27 & 3.51 & 2.92 & 1.88 & 3.06 & 2.34 \\
\hline SD & .80 & 1.38 & 1.37 & 1.11 & 1.28 & .90 & 1.11 & 1.06 \\
\hline
\end{tabular}

Heading codes: 1,2,3,4 - the number of the pair of labeled and unlabeled entries, $\mathrm{y}$ - label present, $\mathrm{n}-$ label absent. The remainder is the name of the entry.

There is a weak, yet not statistically significant, positive correlation between the self-assessment of using the labels and the effect they have (the label use question versus the difference in acceptability between labeled and unlabeled entries [ $\mathrm{R}=.12, \mathrm{p}=.22, \mathrm{~N}=105]$ ).

In the US dataset, there was a significant difference in the level of acceptability for labeled entries $(\mathrm{M}=3.04, \mathrm{SD}=1.34)$ and non-labeled entries $(\mathrm{M}=3.67$, $\mathrm{S}=1.21) ; \mathrm{t}(894)=7.38, \mathrm{p}=.00$. As can be seen, labeled entries have a lower degree of acceptability. The acceptability of individual entries is presented in Table 4.

Table 4: Acceptability of individual entries in the US study

\begin{tabular}{|l|l|l|l|l|l|l|l|l|}
\hline & 1ncram & $\begin{array}{c}1 \text { ychill_ } \\
\text { out }\end{array}$ & 2yscrewed & 2ybamboozle & 3yprick & 3nhang_out & $\begin{array}{l}\text { 4nknocked- } \\
\text { up }\end{array}$ & 4njerk \\
\hline N & 112 & 112 & 112 & 112 & 112 & 112 & 112 & 112 \\
\hline Mean & 4.04 & 3.35 & 3.11 & 3.03 & 2.69 & 4.08 & 3.04 & 3.53 \\
\hline SD & .95 & 1.33 & 1.31 & 1.32 & 1.34 & 1 & 1.29 & 1.27 \\
\hline
\end{tabular}

Heading codes: 1,2,3,4 - the number of the pair of labeled and unlabeled entries, $\mathrm{y}$ - label present, $\mathrm{n}-$ label absent. The remainder is the name of the entry.

There is a weak, yet not statistically significant, positive correlation between the self-assessment of using the labels and the effect they have (the label use 
question versus the difference in acceptability between labeled and unlabeled entries [ $\mathrm{R}=.18, \mathrm{p}=.063]$ ).

What is most remarkable in a comparison between the Slovene and US data is a considerably lower level of acceptance among Slovene students for labeled and unlabeled entries alike. On a scale from 1 (least acceptable) to 5 (most acceptable), the average among Slovene students was 2.76 (2.58 for unlabeled entries and 2.94 for labeled entries) as opposed to the score obtained from the US students of 3.36 (3.04 for unlabeled entries and 3.67 for labeled entries).

\section{Discussion and conclusion}

Dictionaries are often thought of as a record of language. However, dictionaries even if they claim to be only descriptive or only prescriptive - mostly combine both descriptive and prescriptive approaches. This is pointed out by Svensén (2009: 24), who says that "... most general-purpose dictionaries should be characterized as partly normative because, in one way or other, a large portion of what they describe is actually made up of linguistic norms already in existence"; this is also in line with Cameron (1995: 5), who considers this absolute binary distinction between descriptivism and prescriptivism a mistake. An important point that should be emphasized is that in the dictionary, the public often seeks answers to questions about the spelling, pronunciation and the correct usage of words, which means that the public expects at least a certain degree of normativity (Adams 2015: 25). Compilers of a generalpurpose monolingual dictionary should therefore always try to find a balance between descriptive and prescriptive approaches, since both of them affect the users (Adams 2015: 43).

The results obtained in the present research point to the following hypotheses that are consistent with the aforementioned claim about the relation between descriptivism and prescriptivism.

First, in both observed samples, the type of normative labels matters. Primary normative labels are associated with a lower acceptance for the use in the standard language variety than their secondary counterparts. In this survey, primary labels showed a lower level of acceptability (2.60 in the Slovene and 2.97 in the US survey) than their secondary counterparts (2.75 in the Slovene and 3.26 in the US survey). The fact that their effect seems to be stronger in the Slovene sample could be related to a higher degree of prescriptivism in the mainstream Slovene linguistic culture as opposed to a more descriptive approach in the American linguistic culture.

Second, in both samples, there is a disconnect between the cognitive component of attitude toward normative labels and its behavioral component. The approval for the claim that these labels are useful (4.10 in the Slovene and 3.92 in the US survey) is considerably higher than the value for the statement that the respondent uses the labels (3.22 in the Slovene and 3.12 in the US survey). A higher approval for the claim about usefulness of the labels in the Slovene 
sample may be another consequence of a higher level of prescriptivism in that linguistic culture.

Third, the presence of the label makes a difference in terms of the level of acceptance for standard language use in both observed samples. Consequently, labeled entries have a lower level of acceptability (2.58 in the Slovene and 3.04 in the US survey) than their unlabeled counterparts (2.94 in the Slovene and 3.67 in the US survey). A considerably lower general level of acceptance for standard language use among Slovene students (2.76 versus 3.36 in their US counterparts) may, yet again, be related to a higher prominence of prescriptivism in that linguistic culture.

Among the limitations of the study whose results are presented in this paper, we should mention that the study was carried out in the environment of only two languages, i.e., Slovene and American English. Apart from that, the number of respondents and their background (they were all students) was also part of a fairly limited sample, which means that the two gathered were not representative. Consequently, the results should be understood as hypotheses which should be examined in more detail in further studies.

\section{Acknowledgements}

The authors acknowledge the project, The Practice of Normative Labeling in Slovene and American Lexicography (grant number: BI-US/18-20-036), which was financially supported by the Slovene Research Agency. They also acknowledge the approval of the Arizona State University (ASU) Institutional Review Board. Our gratitude goes to Elly van Gelderen, Mariana Bahtchevanova, and Anne Walton-Ramirez for their help with organizing the survey of US students. The authors are also very grateful to the study participants from the undergraduate programs in the School of Economics and Business and the Faculty of Arts at the University of Ljubljana as well as to the students of English and International Letters and Cultures at Arizona State University.

Danko Šipka would also like to thank the ASU Melikian Center and the National Council for Eurasian and East European Research for their financial support of his trip to Slovenia.

\section{Endnotes}

1. In discussing the complexity of the relation between standard and non-standard language forms, a study carried out by Smakman (2012) is of a particular importance. He surveyed over one thousand non-linguists from England, Flanders (a part of Belgium, France and the Netherlands), Japan, as well as other parts of the Netherlands, New Zealand, Poland and the United States and concluded that although the ideas about the standard language have very little in common, one can recognize a socially distinctive (exclusive) notion of the standard language and socially cohesive (integrative) one. The former notion points to the fact that the language form is only used in formal communication (such as the news, official documents, etc.). 
2. This is very much in line with Scherba (1974: 276; cited in Grigoryan 2007: 4-5), who stated: "From a purely linguistic point of view only normative or academic type of dictionaries must be considered scholarly since their subject matter is linguistic reality - i.e. the lexical system of the language in its totality and complexity."

3. IRB approval was secured at Arizona State University in early April 2019 (IRB ID: STUDY00010014).

\section{References}

Adams, Michael. 2015. Language Ideologies and The American Heritage Dictionary of the English Language: Evidence from Motive, Structure, and Design. Dictionaries: Journal of the Dictionary Society of North America 36: 17-46.

Ahačič, Kozma (Ed.). 2015. Slovenske slovnice in pravopisi: spletišče slovenskih slovnic in pravopisov od 1584 do danes. Version 1.0. Accessed on 14 May 2020: https://fran.si/slovnice-in-pravopisi/

Armstrong, Nigel R. and Ian Mackenzie. 2015. On Prescriptivism and Ideology. Representaciones. Revista de Estudios sobre Representación en Arte, Cincia y Filosofía 11(2): 27-58.

Balteiro, Isabela. 2011. Prescriptivism and Descriptivism in the Treatment of Anglicisms in a Series of Bilingual Spanish-English Dictionaries. International Journal of Lexicography 24(3): 277-305.

Béjoint, Henri. 2010. The Lexicography of English: From Origins to Present. Oxford: Oxford University Press.

Brewer, Charlotte. 2010. Prescriptivism and Descriptivism in the First, Second and Third Editions of OED. English Today 26(2): 24-33.

Cameron, Deborah. 1995. Verbal Hygiene. London/New York: Routledge.

Dobrovoljc, Helena. 2004. Pravopisje na Slovenskem. Ljubljana: ZRC SAZU.

Dobrovoljc, Helena. 2015a. Fran Levec. Slovenski pravopis. Ahačič, Kozma (Ed.). 2015. Accessed on 14 May 2020:

https://fran.si/slovnice-in-pravopisi/34/1899-levec

Dobrovoljc, Helena. 2015b. Anton Breznik, Fran Ramovš. Slovenski pravopis. Ahačič, Kozma (Ed.). 2015. Accessed on 14 May 2020:

https://fran.si/slovnice-in-pravopisi/39/1935-breznik-ramovs

Dobrovoljc, Helena. 2015c. Toporišič, Jože (Ed.). [Pravila:] Franc Jakopin, Janko Moder, Janez Dular, Stane Suhadolnik, Janez Menart, Breda Pogorelec, Kajetan Gantar, Martin Ahlin. [Slovar:] Franc Jakopin, Janko Moder, Janez Dular, Milena Hajnšek-Holz. Slovenski pravopis. Ahačič, Kozma (Ed.). 2015. Accessed on 14 May 2020.

https://fran.si/slovnice-in-pravopisi/50/2001-skupinski-toporisicev

Finegan, Edward. 2003. Linguistic Prescription: Familiar Practices and New Perspectives. Annual Review of Applied Linguistics 23: 213-224.

Finegan, Edward. 2020. What Is 'Correct' Language? https://www.linguisticsociety.org/resource/what-correct-language 
Gliha Komac, Nataša, Nataša Jakop, Janoš Ježovnik, Simona Klemenčič, Domen Krvina, Nina Ledinek, Tanja Mirtič, Andrej Perdih, Špela Petric, Marko Snoj and Andreja Žele (Eds.). 2015. Koncept novega razlagalnega slovarja slovenskega knjižnega jezika. Ljubljana: Založba ZRC, ZRC SAZU. Accessed on 14 February 2020:

https://fran.si/179/novi-slovar-slovenskega-knjiznegajezika/datoteke/Potrjeni_koncept_NoviSSKJ.pdf

Gove, Philip B. (Ed.). 1967. The Role of the Dictionary. Indianapolis: Bobbs-Merrill.

Gove, Philip B. 1967. The Dictionary's Function. Gove, Philip B. (Ed.). 1967: 5-8.

Grigoryan, Ashot A. 2007. On Gender Aspect in Lexicography. Karpova, Olga and Faina Kartashkova (Eds.). 2007: 2-10.

Hausmann, Franz Josef. 1989. Die Markierung im allgemeinen einsprachigen Wörterbuch: eine Übersicht. Hausmann, Franz Joseph, Oskar Reichmann, Herbert Ernst Wiegand and Ladislav Zgusta (Eds). 1989: 649-657.

Hausmann, Franz Joseph, Oskar Reichmann, Herbert Ernst Wiegand and Ladislav Zgusta (Eds). 1989. Dictionaries. An International Encyclopedia of Lexicography. Vol. 1. Berlin/New York: Walter de Gruyter.

Hitchings, Henry. 2005. Dr Johnson's Dictionary. London: John Murray.

Jarošová, Alexandra and Vladimír Benko. 2012. The Dictionary of the Contemporary Slovak Language: A Product of Tradition and Innovation. Vatvedt Fjeld, Ruth and Julie Matilde Torjusen (Eds.). 2012: 257-261.

Johnson, Samuel. 1755. A Dictionary of the English Language. London: W. Strahan, for J. \& P. Knapton.

Karpova, Olga and Faina Kartashkova (Eds.). 2007. Essays on Lexicon, Lexicography, Terminography in Russian, American and Other Cultures. Newcastle: Cambridge Scholars Publishing.

Laird, Charlton Grant. 1970. Language in America. New York: World Publishing Company.

Landau, Sidney I. 2001. Dictionaries: The Art and Craft of Lexicography. Second edition. Cambridge: Cambridge University Press.

Lynch, Jack (Ed.). 2003. Samuel Johnson's Dictionary. New York: Walker \& Co.

Lynch, Jack. 2003. Introduction to this Edition. Lynch, Jack (Ed.). 2003: 1-21.

Martin, Peter. 2019. Peter Martin on The Dictionary Wars. Interview on August 26, 2019. Accessed on 16 April 2020:

https://press.princeton.edu/ideas/peter-martin-on-the-dictionary-wars.

Marušič, Franc and Rok Žaucer. 2015. Jože Toporišič. Slovenska slovnica. Ahačič, Kozma (Ed.). 2015. Accessed on 14 May 2020: https://fran.si/slovnice-in-pravopisi/46/1976-toporisic

Miłkowski, Marcin. 2013. On the Social Nature of Linguistic Prescriptions. Psychology of Language and Communication 17(2): 175-187.

Morris, William (Ed). 1969. The American Heritage Dictionary of the English Language. Boston: Houghton Mifflin.

Morton, Herbert C. 1994. The Story of Webster's Third: Philip Gove's Controversial Dictionary and Its Critics. Cambridge: Cambridge University Press.

Scherba, Lev V. 1974. Opit obschei teorii leksikografii (Experience of General Theory of Lexicography). Jazykovaja sistema i rechevaja dejatel'nost' (Language System and Speech Activity): 265-304.

Schulman, Arthur and Jill Lepore. 2008. Websterisms: A Collection of Words and Definitions Set Forth by the Founding Father of American English. New York: Free Press. 
Smakman, Dick. 2012. The Definition of the Standard Language: A Survey in Seven Countries. International Journal of the Sociology of Language 218: 25-58.

Svensén, Bo. 2009. A Handbook of Lexicography: The Theory and Practice of Dictionary-Making. Cambridge: Cambridge University Press.

Šipka, Danko, Alenka Vrbinc and Marjeta Vrbinc. 2020 (in press). Normative Labels in Slovene Dictionaries: Users' and Lexicographers' Perspectives. International Journal of Lexicography 33(4).

Vatvedt Fjeld, Ruth and Julie Matilde Torjusen (Eds.). 2012. Proceedings of the 15th EURALEX International Congress, 7-11 August 2012, Oslo. Oslo: Department of Linguistics and Scandinavian Studies, University of Oslo.

Vrbinc, Alenka, Donna M.T.Cr. Farina and Marjeta Vrbinc. 2018. Objectivity, Prescription, Harmlessness, and Drudgery: Reflections of Lexicographers in Slovenia. Lexikos 28: 361-383.

Yong, Heming and Jing Peng. 2007. Bilingual Lexicography from a Communicative Perspective. Amsterdam: John Benjamins.

Zgusta, Ladislav. 1971. Manual of Lexicography. Prague: Academia / The Hague/Paris: Mouton. 


\section{Appendix 1: Slovene Questionnaire}

1. The following dictionary label means that the word or its meaning is used in standard language (such as news read by TV anchors, or court decisions). Select one option for each label.

\begin{tabular}{|c|c|c|c|c|c|}
\hline colloquial & $\square$ always & $\square$ often & $\square$ sometimes & $\square$ rarely & $\square$ never \\
\hline dialectal & $\square$ always & $\square$ often & $\square$ sometimes & $\square$ rarely & $\square$ never \\
\hline expressive & $\square$ always & $\square$ often & $\square$ sometimes & $\square$ rarely & $\square$ never \\
\hline facetious & $\square$ always & $\square$ often & $\square$ sometimes & $\square$ rarely & $\square$ never \\
\hline incorrect & $\square$ always & $\square$ often & $\square$ sometimes & $\square$ rarely & $\square$ never \\
\hline ironic & $\square$ always & $\square$ often & $\square$ sometimes & $\square$ rarely & $\square$ never \\
\hline obsolete & $\square$ always & $\square$ often & $\square$ sometimes & $\square$ rarely & $\square$ never \\
\hline vulgar & $\square$ always & $\square$ often & $\square$ sometimes & $\square$ rarely & $\square$ never \\
\hline
\end{tabular}

2. Labels (for example, coll - colloquial, vulg - vulgar) are a useful part of the dictionary.

$\square$ strongly agree $\quad \square$ agree $\quad \square$ no opinion $\quad \square$ disagree $\quad \square$ strongly disagree

3. When I use dictionaries I pay attention to the labels (for example, coll - colloquial, vulg - vulgar).

$\square$ strongly agree $\quad \square$ agree $\quad \square$ no opinion $\quad \square$ disagree $\quad \square$ strongly disagree

4. Is the difference between colloquial and lower colloquial useful?

$\square$ strongly agree $\quad \square$ agree $\quad \square$ no opinion $\quad \square$ disagree $\quad \square$ strongly disagree

5. The word in bold are used in standard language

bákšiš -a m pog. napitnina, podkupnina

$\square$ strongly agree $\quad \square$ agree $\quad \square$ no opinion $\quad \square$ disagree $\quad \square$ strongly disagree

cóprnik -a m čarovnik

$\square$ strongly agree $\quad \square$ agree $\quad \square$ no opinion $\quad \square$ disagree $\quad \square$ strongly disagree

déci m neskl. pog. deciliter

$\square$ strongly agree $\quad \square$ agree $\quad \square$ no opinion $\quad \square$ disagree $\quad \square$ strongly disagree

fájfa -e ž pog. priprava za kajenje, ki se napolni s tobakom; pipa

$\square$ strongly agree $\quad \square$ agree $\quad \square$ no opinion $\quad \square$ disagree $\quad \square$ strongly disagree

sekírati -am nedov. s pretiranimi zahtevami povzročati komu neprijetnosti, slabo voljo

$\square$ strongly agree $\quad \square$ agree $\quad \square$ no opinion $\quad \square$ disagree $\quad \square$ strongly disagree

déka ${ }^{2}$-e ž pog. (volnena) odeja

$\square$ strongly agree $\quad \square$ agree $\quad \square$ no opinion $\quad \square$ disagree $\quad \square$ strongly disagree

hóhštápler -ja m domišljav človek, gizdalin

$\square$ strongly agree $\quad \square$ agree $\quad \square$ no opinion $\quad \square$ disagree $\quad \square$ strongly disagree

déka ${ }^{1}$-e ž dekagram

$\square$ strongly agree $\quad \square$ agree $\quad \square$ no opinion $\quad \square$ disagree $\quad \square$ strongly disagree 


\section{Appendix 2: $\quad$ US Questionnaire}

1. When we look a word up in a dictionary, we sometimes find a label on it like these listed below. Does that mean that we can always use such words in standard English (such as news read by TV anchors, or court decisions) or never, or somewhere in between? Select one option for each label.

$\begin{array}{llllll}\text { colloquial } & \square \text { always } & \square \text { often } & \square \text { sometimes } & \square \text { rarely } & \square \text { never } \\ \text { dialectal } & \square \text { always } & \square \text { often } & \square \text { sometimes } & \square \text { rarely } & \square \text { never } \\ \text { expressive } & \square \text { always } & \square \text { often } & \square \text { sometimes } & \square \text { rarely } & \square \text { never } \\ \text { facetious } & \square \text { always } & \square \text { often } & \square \text { sometimes } & \square \text { rarely } & \square \text { never } \\ \text { incorrect } & \square \text { always } & \square \text { often } & \square \text { sometimes } & \square \text { rarely } & \square \text { never } \\ \text { ironic } & \square \text { always } & \square \text { often } & \square \text { sometimes } & \square \text { rarely } & \square \text { never } \\ \text { obsolete } & \square \text { always } & \square \text { often } & \square \text { sometimes } & \square \text { rarely } & \square \text { never } \\ \text { vulgar } & \square \text { always } & \square \text { often } & \square \text { sometimes } & \square \text { rarely } & \square \text { never }\end{array}$

2. Labels (for example, coll - colloquial, vulg - vulgar) are a useful part of the dictionary.

$\square$ strongly agree $\quad \square$ agree $\quad \square$ no opinion $\quad \square$ disagree $\quad \square$ strongly disagree

3. When I use dictionaries I pay attention to the labels (for example, coll - colloquial, vulg - vulgar).

$\square$ strongly agree $\quad \square$ agree $\quad \square$ no opinion $\quad \square$ disagree $\square$ strongly disagree

4. It would be useful if dictionaries would differentiate between colloquial and lower colloquial.

$\square$ strongly agree $\quad \square$ agree $\quad \square$ no opinion $\quad \square$ disagree $\square$ strongly disagree

5. Is the word in bold used in standard English (such as news read by TV anchors, or court decisions)?

cram $\mathrm{v}$ to study for an examination by memorizing facts at the last minute

$\square$ strongly agree $\quad \square$ agree $\square$ no opinion $\quad \square$ disagree $\square$ strongly disagree

chill out $\mathrm{v}$ slang to calm down; to relax

$\square$ strongly agree $\square$ agree $\square$ no opinion $\quad \square$ disagree $\square$ strongly disagree

screwed adj slang bilked; cheated

$\square$ strongly agree $\quad \square$ agree $\quad \square$ no opinion $\quad \square$ disagree $\quad \square$ strongly disagree

bamboozle $\mathrm{v}$ informal to practice trickery, deception, cozenage, or the like

$\square$ strongly agree $\quad \square$ agree $\quad \square$ no opinion $\quad \square$ disagree $\quad \square$ strongly disagree

prick $\mathrm{n}$ slang an obnoxious or contemptible person

$\square$ strongly agree $\quad \square$ agree $\quad \square$ no opinion $\quad \square$ disagree $\quad \square$ strongly disagree

hang out $\mathrm{v}$ to loiter in public places

$\square$ strongly agree $\quad \square$ agree $\quad \square$ no opinion $\quad \square$ disagree $\quad \square$ strongly disagree

knocked-up adj made pregnant

$\square$ strongly agree $\quad \square$ agree $\quad \square$ no opinion $\quad \square$ disagree $\square$ strongly disagree

jerk $\mathrm{n}$ a contemptibly naive, fatuous, foolish, or inconsequential person.

$\square$ strongly agree $\quad \square$ agree $\quad \square$ no opinion $\quad \square$ disagree $\quad \square$ strongly disagree 